解説 機能性イオン交換体シリーズ 1-3

\title{
マンガン酸化物イオンふるい結晶(3) 海水リチウム採取への応用
}

\section{大井 健太 ${ }^{1}$, 宮井 良孝 ${ }^{1}$, 加納 博文 $^{1}$, 馮 旗 $^{2}$}

\author{
1 四国工業技術研究所 \\ 干761-03 高松市林町 2217-14 \\ 2 高知大学理学部附属水熱化学実験所 \\ 干780 高知市曙町 2-5-1
}

(1997 年 11 月 10 日受理)

\begin{abstract}
要 旨
イオンふるい結晶の一種であるスピネル型マンガン酸化物はリチウムイオンに対して特異的 選択吸着性を示し, 海水からのリチウム採取用吸着剂として最も有望な材料である。近い将 来, 需要量の增大が予想されているリチウムを海水から採取する技術の確立を目的として, ス ピネル型マンガン酸化物系吸着剤の開発, 粉末吸着剤の造粒とりチウム吸着性, カラム吸着一 脱着条件の検討,リチウム採取ベンチ試験を行った。これらの結果に基ついて効率的なリチウ ム採取プロセスを提案し，さらに実用化に向けて今後の課題を考察した。

$(\mathrm{Li})\left[\mathrm{Li}_{0.33} \mathrm{Mn}(\mathrm{IV})_{1.67}\right] \mathrm{O}_{4}$ に近い化学組成の前駆体を酸処理してリチウムを溶出した試料が 最も高いリチウム吸着性を示した。海水からのリチウム吸着量は $20 \mathrm{mg} \cdot \mathrm{g}^{-1}$ 以上に達し，鉱 石なみのリチウム含量となった。ポリ塩化ビニルをバインダーとして得られた造粒体が良好な リチウム吸着性能を示した。流動床方式によるカラム吸着及び酸脱着試験を行い, 実験室規模 での吸脱着特性を明らかにした。その結果に基づいてベンチ試験装置を試作し, $\mathrm{kg}$ レベルの リチウムを海水から回収することに成功した。今後の課題として, 更に安定な吸着剤の開発と 効率的な吸着システムの構築を提案した。
\end{abstract}

\section{1. はじめに}

本シリーズの(1)と(2)において, マンガン酸化物 イオンふるい結晶の基礎的な特性について解説し た。ここでは，むしろ応用といら観点からスピネ ル型マンガン酸化物による海水中のリチウム採取 に関する研究結果を紹介したい。

著者らの所属する四国工業技術研究所は海洋資 源開発を中心課題として研究を進めている。分離 工学研究室では海水に溶存する無機有価成分の回
収に関する研究に長期間取り組んでいる。海水は 低濃度ながらリチウムを含んで括り，その総量は 2,300 億トンに達する。リチウム鈗石のない我が 国では海水は重要なリチウム資源と考えることが できる。

濃度の低い海水などからリチウムを採取する場 合, 経済性, 操作性, 採取効率, 環境保全などを 考えると吸着法が最も適当な採取法であろら。吸 着法による採取システムの構築のためには，(1)高 
性能リチウム吸着剂の開発, (2)経済的な採取シス テムの開発, の 2 点が最も重要な課題となる。 吸着剤の開発研究についてはこの 20 年間に多く の報告がなされ，既に総説としてまとめられてい る1)。今までの研究結果を総合すると,イオンふ るい結晶の一つであるスピネル型マンガン酸化物 が最も実用化に近い有望な吸着剤であると結論さ れる。

一方, 採取システムの開発に関しては研究の端 緒についたところであり, 火力発電所温排海水を 用いる方法, 採取船舶を利用する方法, 波力発電 設備を利用する方法などが提案されている。採取 システムの研究が進むにつれて，吸着剤に対する 評価も, 単にリチウム吸着量の大小だけでなく吸
着プロセスを想定した化学工学的な性能評価が必 要な段階に至っている。

ここでは, スピネル型マンガン酸化物系吸着剤 の合成条件, 造粒法, カラム吸脱着試験, ベンチ 試験など著者らのこれまでの研究結果を概説す る。

\section{2. スピネル型マンガン酸化物吸着剤}

スピネル構造のリチウムマンガン酸化物やマグ ネシウムマンガン酸化物を酸処理し, 結晶構造を 保ったままでリチウムやマグネシウムを溶出する とスピネル型マンガン酸化物（以下, 吸着剤と呼 ぶ）が得られる。これらの試料中には四面体型あ るいは八面体型吸着サイトが多数形成されてい

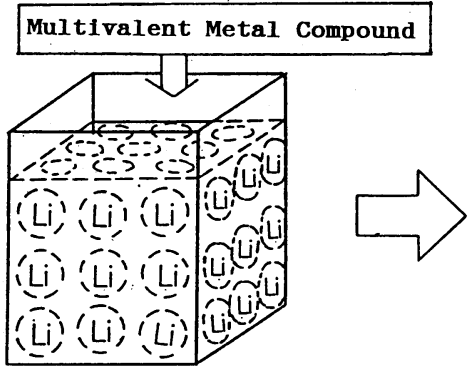

Introduce Li followed by heat treatment

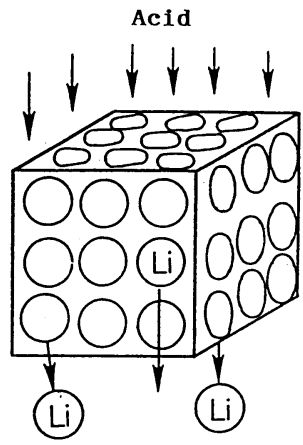

Extraction of Li with acid

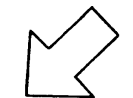

\section{Lithium Ion-sieve Crystal}

\section{Behavior in Solution}
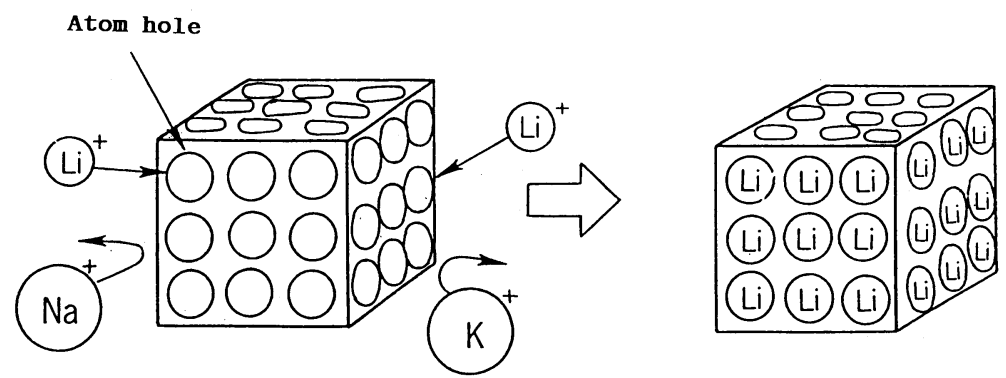

Fig. 1 Preparation of spinel type manganese oxide and its lithium ion-sieve propery. 
る。吸着サイトは非常に狭いためイオン半径の小 さなリチウムだけが選択的に吸着される。イオン ふるい吸着剤の合成プロセス及びイオンふるい作 用を模式的に Fig. 1 に示す。

リチウム吸着性は吸着剤の合成法や合成条件に 大きく依存する。各種方法で調製した吸着剤の海 水からのリチウム吸着量をTable 1 にまとめて いる。 $\mathrm{MnCO}_{3}$ と $\mathrm{Li}_{2} \mathrm{CO}_{3}$ とを $\mathrm{Li} / \mathrm{Mn}$ 比 0.8 で混 合し, ガス雾囲気を制御してロータリンキルン中 $400^{\circ} \mathrm{C}$ で加熱処理した試料を前駆体として合成し た吸着剂2)が最も高い吸着量を示す。本前駆体 は，典型的なスピネル型リチウムマンガン酸化物 の一つである (Li) $\left[\mathrm{Li}_{0.33} \mathrm{Mn}(\mathrm{IV})_{1.67}\right] \mathrm{O}_{4}$ に近い化 学組成を示し，ほとんどがイオン交換型サイト (本シリーズ(1)参照) であることを特徴とする。 また，マンガンの価数がほぼ 4 であるため，化 学的に安定であり吸着剂として好適である。海水 中でのリチウム吸着量は $20 \mathrm{mg} / \mathrm{g}$ 以上に達し, リチウム含量は $\mathrm{Li}_{2} \mathrm{O}$ 換算で $4 \%$ 以上となる。リ チウム鉱石中のリチウム含量が $\mathrm{Li}_{2} \mathrm{O}$ 換算で 3 9\%であるので，吸着剤を海水に浸せきするだけ で人工のリチウム鉱石が得られることになる。

マグネシウムマンガン酸化物を酸処理した試料
もリチウム吸着性を示すのは興味深い3,4)。マグ ネシウムの有効イオン半径はリチウムイオンとほ ぼ同じであるため，マンガン酸化物内にはリチウ 么の場合と同程度の大きさの空隙が形成されてい ると推測される。また，リチウムイオンの水和エ ネルギーはマグネシウムイオンの $1 / 4$ ほどなの で, 海水中のリチウムはマグネシウムイオンより も容易に脱水和して吸着剂中に入ることができ る。

\section{3. 吸着剂の造粒}

\section{1 造粒法}

海水のリチウム濃度が低いことから, 工業的に リチウムを採取するためには吸着剤を大量の海水 と効率よく接触させなければならない。吸着時の 圧力損失が少なく，かつ海水との接触効率も良好 な流動床方式が最も適当な吸着プロセスであると 考えられる。従って，吸着剤の飛散を防ぐために 粉末吸着剤の造粒が必要となる。

造粒した吸着剤は, 物理的及び化学的安定性が 高いだけでなく，粉末時の吸着性能をできるだけ 保持する必要がある。特に, マンガンは酸化還元 反応を容易に起こす元素であるため，酸化還元反

Table 1 Lithium uptakes by spinel type manganese oxides obtained by different preparation methods

\begin{tabular}{|c|c|c|}
\hline Preparation method of precursor & $\begin{array}{l}\text { Heating temp. } \\
\left({ }^{\circ} \mathrm{C}\right)\end{array}$ & $\begin{array}{l}\text { Lithium uptake from } \\
\text { seawater } / \mathrm{mg} \mathrm{g}^{-1}\end{array}$ \\
\hline $\mathrm{MnCO}_{3}+\mathrm{Li}_{2} \mathrm{CO}_{3}, \mathrm{Li} / \mathrm{Mn}=0.8$, rotary kiln & 400 & $12^{\mathrm{a})}$ \\
\hline $\mathrm{MnOOH}+\mathrm{Li}_{2} \mathrm{CO}_{3}, \mathrm{Li} / \mathrm{Mn}=0.75$ & 400 & 6.5 \\
\hline$=0.50$ & 400 & 4.7 \\
\hline$=0.50$ & 820 & 1.1 \\
\hline$=0.20$ & 400 & 1.8 \\
\hline$=0.20$ & 820 & 4.1 \\
\hline \multirow[t]{3}{*}{$\gamma-\mathrm{MnO}_{2}+\mathrm{LiOH}(\mathrm{aq})$} & 400 & $<0.1$ \\
\hline & 580 & 3.5 \\
\hline & 750 & 4.1 \\
\hline \multirow[t]{2}{*}{$\mathrm{MnCl}_{2}(\mathrm{aq})+\mathrm{LiOH}(\mathrm{aq}), \mathrm{Li} / \mathrm{Mn}=1.2$} & 450 & 6.0 \\
\hline & 820 & 1.2 \\
\hline$\gamma-\mathrm{MnOOH}+\mathrm{Mg}(\mathrm{OH})_{2}, \mathrm{Mg} / \mathrm{Mn}=0.5$ & 950 & 4.5 \\
\hline \multirow[t]{2}{*}{$\mathrm{MnCl}_{2}+\mathrm{MgCl}_{2}, \mathrm{Mg} / \mathrm{Mn}=2$} & 500 & 2.7 \\
\hline & 800 & 4.8 \\
\hline
\end{tabular}

Adsorbent: $50 \mathrm{mg}$ (a: $25 \mathrm{mg}$ ), seawater: $2 \mathrm{dm}^{3}$, temp. $25^{\circ} \mathrm{C}$. 
応に強い:゙インダーが求められる。約 50 種の有 機及び無機系バインダーを用いて造粒の予備試験 を行い,ポリ塩化ビニル (PVC) が最も良好な バインダーであることを見いだした5)。造粒装置 をFig. 2 に示す。ポリ塩化ビニル（PVC）をジ メチルホルムアミド (DMF) 溶かした溶液に前 駆体粉末（リチウムマンガン酸化物）を懸濁させ る。懸濁液を水ーアルュール混合溶液中に滴下さ せポリ塩化ビニルを不溶化させて粒状体を調製す る。この装置を用いれば，Fig. 3 に示すよらな 球状の粒子を大量に合成することができる。 PVCを 20 重量\%添加すれば, 粒子は十分な物理 的強度を示す。電子顕微鏡観察に上れば，粒子の 表面は滑らかであるが, 約 $1 \mu \mathrm{m}$ 注どの孔が多数 形成されている。これは有機溶媒の DMF が粒子 から混合水溶液相に移行するときに形成されると 考兄らる。球表面上のこのような孔はリチウム の粒内への移動を円滑にする。一方, 球内部では 吸着剂粉末が比較的緩やかに集合している。

粒状吸着剂の真密度と湿潤粒子密度はそれぞれ 3.50 及び $1.36 \mathrm{~g} \cdot \mathrm{cm}^{-1}$ と測定された。これから 粒子の空隙率を計算すると 0.86 となり，粒子は 比較的空隙の多い構造をとっている。

\section{2 粒状吸着剤のバッチ吸着特性}

粉末及び粒状吸着剤のリチウム吸着等温線を Fig. 4 に示す6)。等温線はフロインドリッヒ式に 従う。粒状吸着剤は粉末よりも小さなリチウム吸 着量を示すが，PVC 含量を補正すれば粉末と汪 ぼ同じ值となり PVC 添加の影響はほとんど受け ない。PVCを $20 \%$ 添加した粒状体の海水濃度で のリチウム吸着量は $18 \mathrm{mg} / \mathrm{g}$ となり,この際の リチウム含量は酸化リチウムとして約 $4 \%$ に達 している。

吸着剂の性能としては平衡論的な吸着能だけで なく吸着速度が重要な要素となる。粒状吸着剂に 扣けるリチウムの粒内拡散係数をバッチ法で求め た7)。粒内拡散係数の解析にあたって球形粒子を

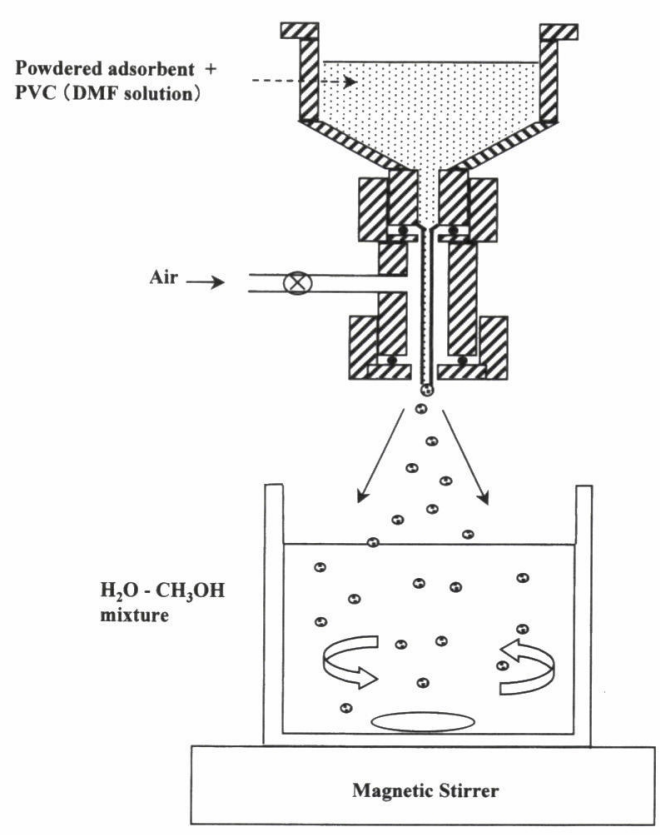

Fig. 2 Apparatus for granulation.

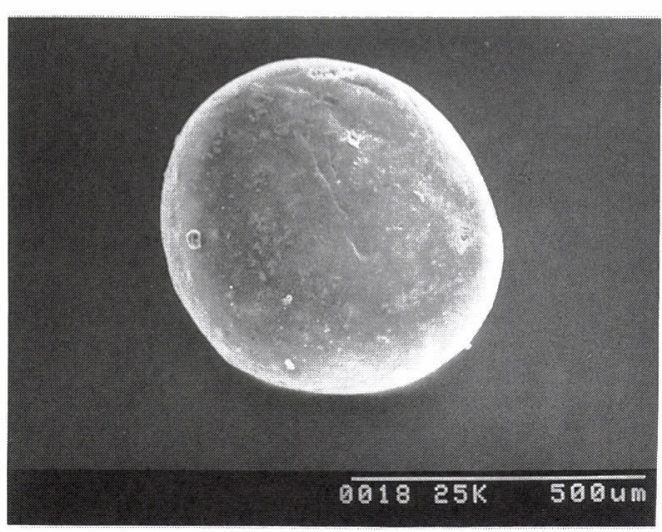

Fig. 3 SEM photograph of granulated adsorbent.

仮定し，さらに(1)粒子表面に拈ける境膜物質移動 抵抗は無視できる, (2)表面拡散は無視できる, (3) 粒子内の固液界面に拈ける吸着等温線はフロイン ドリッヒ式に従う,の 3 点を仮定した。

基礎方程式群は以下のようと与えられる8)。 吸着槽内の物質収支

$$
-\mathrm{V}(\partial \mathrm{C} / \partial \mathrm{t})=\mathrm{A} \cdot \mathrm{Dp}(\partial \mathrm{c} / \partial \mathrm{r})_{\mathrm{r}=\mathrm{R}}
$$

粒子内の物質収支 


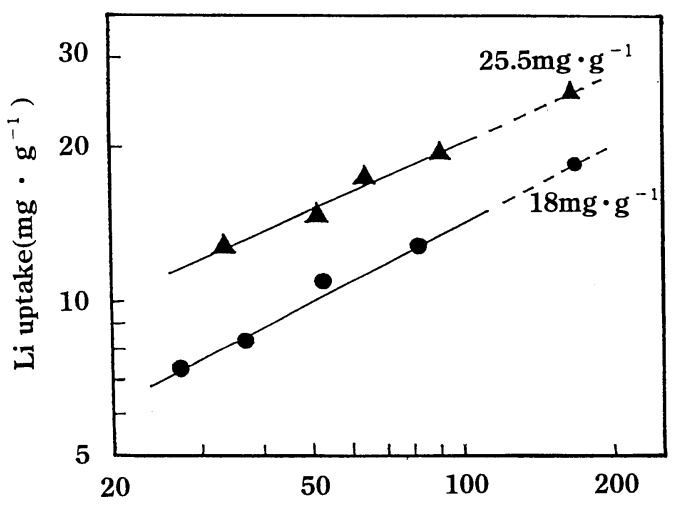

Li concentration $\left(\mu \mathrm{g} \cdot \mathrm{dm}^{-3}\right)$

Fig. 4 Adsorption isotherm of lithium on powdered and granulated adsobent.

Adsorbent: $15-60 \mathrm{mg}$, seawater: $2 \mathrm{dm}^{3}$, temp.: $25^{\circ} \mathrm{C}$.

$\boldsymbol{\Delta}$ : powdered adsorbent, $\bullet$ : granulated adsorbent (0.25-0.5 mm, added PVC: $20 \%$ ).

$$
\operatorname{Dp}\left\{\partial^{2} \mathrm{c} / \partial \mathrm{r}^{2}+(2 / \mathrm{r})(\partial \mathrm{c} / \partial \mathrm{r})\right\}=\rho_{\mathrm{A}}(\partial \mathrm{q} / \partial \mathrm{t})
$$

フロインドリッヒ吸着等温式

$$
\mathrm{q} / \mathrm{Q}_{0}=\left(\mathrm{c} / \mathrm{C}_{0}\right)^{1 / \mathrm{n}}, \mathrm{Q} / \mathrm{Q}_{0}=\left(\mathrm{C} / \mathrm{C}_{0}\right)^{1 / \mathrm{n}}
$$

初期条件

$$
\mathrm{t}=0 \text { に拉いて, } \mathrm{C}=\mathrm{C}_{0}, \mathrm{q}=\mathrm{c}=0
$$

なお，記号の意味は本文末尾に示した。これら の方程式はそれぞれ無次元化した後, あるnの 値について数値計算し解くことができる。

有限槽内での吸着では液中リチウム濃度が吸着 にともなって変化する。一方, 無限槽の場合, 液 中リチウム濃度は一定に保たれる $\left(\mathrm{C}=\mathrm{C}_{0}\right)$ 。有 限槽及び無限槽内における吸着速度の数値解析曲 線は既に文献8)に与只られている。理論曲線は, 溶液中の濃度比 $\left(\mathrm{C} / \mathrm{C}_{0}\right)$ を無次元化時間 $\tau[\tau=$ $\left.\left(\mathrm{Dp} \cdot \mathrm{t} / \mathrm{R}^{2}\right)\left(\mathrm{C}_{0} / \rho_{\mathrm{A}} \cdot \mathrm{Q}_{0}\right)\right]$ の対数値に対して与兄ら れている。

粒径の異なる吸着剤を用いて乱流条件下でバッ チ吸着速度実験を行った結果を Fig. 5 に示す。 上澄みのリチウム濃度の変化を吸着時間（対数目 盛り）に対してプロットしている。いずれの場合

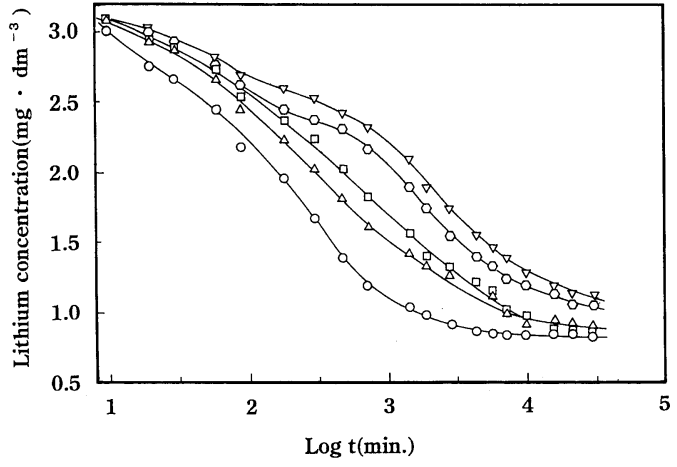

Fig. 5 Concentration decay curves for granulated adsorbent.

Adsorbent: $600 \mathrm{mg}$, lithium enriched seawater $(3.7 \mathrm{ppm}): 2 \mathrm{dm}^{3}$.

Particle size; $\nabla: 1.4-2 \mathrm{~mm}, \quad: 1.0-1.4 \mathrm{~mm}$, ㅁ: $0.7-1.0 \mathrm{~mm}, \Delta: 0.5-0.7 \mathrm{~mm}, 0: 0.25-$ $0.5 \mathrm{~mm}$

も典型的な S 字形曲線を与えている。また，粒 径が小さくなるほど吸着速度が速くなる傾向を示 している。粒径の大きな試料では曲線の途中に段 差がみられ，2段階の吸着過程が示唆される。こ の吸着速度曲線と理論曲線から $\tau$ vs. $t$ プロット を行らことができ，その傾きから粒内拡散係数 （Dp）を計算できる。

計算結果をTable 2 に示す。Dp 值は，ほぼ $2 \times 10^{-6} \mathrm{~cm}^{2} \cdot \mathrm{s}^{-1}$ となり, 粒径依存性は汪とんど 見られない。この Dp 值について議論するために は水溶液中に打けるリチウムイオンの自己拡散係 数值が必要である。しかしながら，水溶液中のリ チゥムイオンの自己拡散係数値は報告されていな い。一般に塩の拡散係数は陽イオンと陰イオンの 拡散係数の平均値 $(\mathrm{D}=2 \mathrm{DcDa} /(\mathrm{Dc}+\mathrm{Da}) ; \mathrm{Dc}$ と Da はそれぞれ陽及び陰イオンの拡散係数）で与 兄られる。 $\mathrm{LiCl}$ の拡散係数 $\left(1.35 \times 10^{-5} \mathrm{~cm}^{2}\right.$ ・ $\left.\mathrm{s}^{-1}\right)$ と $\mathrm{Cl}^{-}$の自己拡散係数 $\left(1.77 \times 10^{-5} \mathrm{~cm}^{2}\right.$. $\left.\mathrm{s}^{-1}\right)$ からリチウムイオンの自己拡散係数を計算 すると $9 \times 10^{-6} \mathrm{~cm}^{2} \cdot \mathrm{s}^{-1}$ なる值が得られる。こ の值と計算された粒内拡散係数を比較すると注 同じオーダーとなっており, 吸着剤中でのリチウ ムイオンの拡散は海水中での拡散ほど速くはない 
Table 2 Intraparticle lithium diffusivity determined by the batch method

\begin{tabular}{cccc}
\hline \hline $\begin{array}{c}\text { Sieve mesh } \\
\mathrm{mm}\end{array}$ & $\begin{array}{c}\overline{\mathrm{R}} \\
\mathrm{cm}\end{array}$ & $\begin{array}{c}\tau / \mathrm{t} \\
\mathrm{s}^{-1}\end{array}$ & $\begin{array}{c}\mathrm{Dp} \\
\mathrm{cm}^{2} \cdot \mathrm{s}^{-1}\end{array}$ \\
\hline $0.25-0.50$ & 0.019 & $1.7 \times 10^{-6}$ & $1.8 \times 10^{-6}$ \\
$0.50-0.71$ & 0.030 & $6.8 \times 10^{-7}$ & $1.8 \times 10^{-6}$ \\
$0.71-1.0$ & 0.043 & $4.1 \times 10^{-7}$ & $2.2 \times 10^{-6}$ \\
$1.0-1.4$ & 0.060 & $1.9 \times 10^{-7}$ & $2.0 \times 10^{-6}$ \\
$1.4-2.0$ & 0.085 & $1.2 \times 10^{-7}$ & $2.5 \times 10^{-6}$ \\
\hline$\rho_{\mathrm{A}}=0.5 \mathrm{~g} \cdot \mathrm{cm}^{-3}, \quad \rho=3.50 \mathrm{~g} \cdot \mathrm{cm}^{-3}$, & $\rho_{\mathrm{w}}=1.36 \mathrm{~g} \cdot$ \\
$\mathrm{cm}^{-3}, \quad \mathrm{C}_{0}=3.1 \times 10^{-6} \mathrm{~g} \cdot \mathrm{cm}^{-3}, \quad Q_{0}=1.8 \times 10^{-2} \mathrm{~g} \cdot$ \\
$\mathrm{g}^{-1}, \mathrm{C}_{\infty} / \mathrm{C}_{0}=0.26, \mathrm{n}=3$.
\end{tabular}

が，あまり大きな抵抗を受けないことがわかる。

平行細孔（parallel pore）モデルでは，Dpは 溶液中のリチウムの自己拡散係数 $\left(\mathrm{D}_{\mathrm{Li}}\right)$ と以下 の式で関係づけられる9)。

$$
\mathrm{Dp}=\varepsilon_{\mathrm{A}} \mathrm{D}_{\mathrm{Li}} / \mathrm{k}^{2}
$$

ここで, $\mathrm{k}^{2}$ は細孔の屈曲度である。本試料の屈 曲度は約 4 と計算され, 活性炭やゼオライトと 同程度である。

無次元化時間が 0.05 以上では， $\tau$ vs. $t$ プロッ トの傾きが小さくなり, 拡散速度が落ちる。この ことは, リチウムイオンの拡散が 2 段の速度過 程で進むことを示唆している。本吸着剤は, 粒径 $10 \mu \mathrm{m}$ 以下の粉末マンガン酸化物を PVC で造粒 しているため, 速度過程が 2 段階になることは 充分に予測される。速い速度過程は粒状体内のリ チウムの拡散, 遅い速度過程は, 粉末内へのリチ ウムの桩散に基づくものと考兄られる。

\section{4. カラム吸脱着試験}

\section{1 カラム吸着}

粒状吸着剂を内径 $2 \mathrm{~cm}$ のカラムに充てんし上 向流で $25^{\circ} \mathrm{C}$ の海水を空間速度 $360 \mathrm{~h}^{-1}$ 通過させ カラム吸着実験を行った6)。粒径の異なる吸着剤 についての結果を Fig. 6 に示す。粒径が小さく なるほど吸着速度は大きくなる傾向が認められ る。
このカラム吸着速度曲線と吸着等温線を用い て，無限容積液内での吸着を仮定してリチウムの 粒内拡散係数を求めることができる。フロインド リッヒ型吸着等温線に基づく無限容積液内での数 値計算結果は $\mathrm{Q} / \mathrm{Q}_{0}$ vs. $\tau$ 曲線として文献中に示 されている8)。 $\tau$ vs. $\mathrm{t}$ プロットは粒径が $0.7 \mathrm{~mm}$ 以上の試料では注㯰線関係を与光, その傾きか ら粒内拡散係数を計算できる。粒内拡散係数は, 約 $4 \times 10^{-6} \mathrm{~cm}^{2} \bullet \mathrm{s}^{-1}$ となり, バッチ法で求めた 值より少し大きいが注ぼ同程度である。拆散係数 値は粒径が小さくなる注ど低下する傾向を示す が，これは粒径が小さな試料では吸着に伴う液中 リチウム濃度の低下による影響がでるためと考兄 られる。以上の解析結果は, 空間速度 $360 \mathrm{~h}^{-1}$ の 条件ではリチウム吸着は粒内拡散律速であること を示している。

海水流速を変えてリチウム吸着性を測定し空間 速度の影響について調べた。粒径 $1.0 \sim 1.4 \mathrm{~mm}$ の粒状吸着剂を用い, 空間速度 $60 \sim 500 \mathrm{~h}^{-1}$ の 条件で通水し, 吸着時間 7 日抗よび 14 日でのリ チウム吸着量を求めた。空間速度 $110 \mathrm{~h}^{-1}$ 以下で は通液速度による影響が認められたが, 空間速度 $220 \mathrm{~h}^{-1}$ 以上ではリチウム吸着量はほぼ一定にな った。吸着量が一定となる領域では境膜抵抗が小 さくなり，粒内拡散が律速になったと推定され

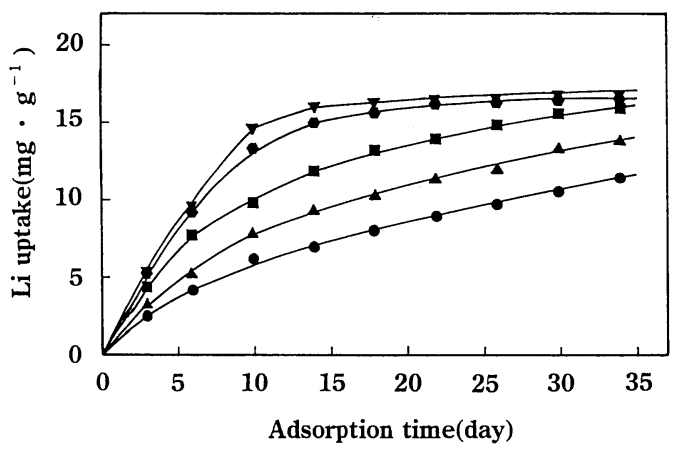

Fig. 6 Column adsorption curves.

Adsorbent: $5 \mathrm{~g}$, column diameter: $2 \mathrm{~cm}$, space velocity: $360 \mathrm{~h}^{-1}$, temp. $25^{\circ} \mathrm{C}$.

Particle size; $\bullet: 1.4-2 \mathrm{~mm}, \mathbf{\Delta}: 1.0-1.4 \mathrm{~mm}$, - : $0.7-1.0 \mathrm{~mm}, \quad: 0.5-0.7 \mathrm{~mm}, \mathbf{\nabla}: 0.25-$ $0.5 \mathrm{~mm}$. 
る。

流動層方式の吸着プロセスを考兵る場合, 吸着 床の膨張が装置条件を決定する際に重要となる。 そのため, 粒径と流動層体積比との関係を検討し た。線速度が $10 \mathrm{~cm} \cdot \mathrm{min}^{-1}$ を越えると吸着床の 体積が膨張し, 流動状態が始まった。また, 流動 層体積比は粒径に大きく依存し, 同じ流速では小 さい粒子注ど膨張しやすいことがわかった。特 に, 粒径の最も小さな試料（粒径 $0.25 \sim 0.5$ $\mathrm{mm}$ ) の場合, 線速度 $40 \mathrm{~cm} \cdot \mathrm{min}^{-1}$ では体積は 2 倍に膨張した。

以上の結果を総合すると, 実用的な吸着剂とし ては吸着速度と流動床容積とのかねあいから粒径 0.7 1.4 mm 程度が好ましいと結論される。

\section{2 カラム脱着}

マンガン酸化物系吸着剂は弱酸性イオン交換体 であるため, アルカリ性領域で吸着反応, 酸性領 域で脱着反応を示す。従って, 吸着剂を $\mathrm{pH} 3$ 以 下の酸性溶液中に浸せきすれば脱着できる。吸着 したリチウムの脱着法として回分式多段脱着法, カラム脱着法について検討したが，ここではカラ ム脱着法を紹介する10)。

海水からリチウムを吸着した粒状吸着剂（リチ ウム吸着量 $\left.16.5 \mathrm{mg} \cdot \mathrm{g}^{-1}\right) 10 \mathrm{~cm}^{3}$ を内径 $0.8 \mathrm{~cm}$, 長さ $30 \mathrm{~cm}$ の硝子製カラムに充填し， $0.1 \sim 2 \mathrm{M}$ 塩酸溶液を空間速度 $0.65 \mathrm{~h}^{-1}$ で下向流にて通液 し, 分画量 $5 \mathrm{~cm}^{3}$ の条件で脱着試験を行った。 回分式と同様に吸着剂中のリチウム含量および溶 出リチウム濃度, マンガン溶出率などを求めた。

酸濃度が高くなると少量の脱着液で脱着できるた めリチウム濃度は高くなった。しかしながら、マ ンガンの溶出率は酸濃度とともに高くなるため塩 酸濃度としては $0.5 \mathrm{M}$ が適当であると結論され た。

酸濃度 $0.5 \mathrm{M}$ のカラム脱着試験の結果を Fig. 7 に示す。吸着剂量の 1.5 倍の脱着液量でリチウ ム脱着率 $92 \%$ に達する。溶出液のリチウム濃度
は最高で $1,400 \mathrm{mg} \cdot \mathrm{dm}^{-3}$ に達し, マンガンの溶 出率は $1.5 \%$ である。他の吸着元素（カルシウ ム, マグネシウム, ナトリウム，カリウム）もリ チウムと注同時に溶出して拉り, カラム脱着に よるリチウムと他元素の分離は困難と考兄られ る。

吸着剤中のマンガンの溶出は, リチウムの溶出 より少し遅れて進む。リチウムの溶出が終るとマ ンガンの溶出量も急激に低下した。溶出の初期段 階ではイオン交換反応に基づく脱着, 次いで酸化 還元反応に基づく脱着（3 価マンガンの不均化反 応を伴ら）が進行していると考えられる。酸化還 元反応の場合, 溶離リチウム 2 分子に対して 1 分子のマンガンが溶出する。そこで両元素の溶出 モル比から反応の割合を計算すると, イオン交換 反応脱着が $70 \%$, 酸化還元反応脱着が $30 \%$ 程度 と推定される。今回の吸着剤中には, 一部 3 価 のマンガンが存在し，これによって不均化反応が 進行すると考觉られる。マンガンの溶出を抑える ためには，3 価のマンガンの更に少ない吸着剤を 合成する必要がある。

\section{3 吸着一脱着の繰り返し試験}

同じ吸着剂を用いてカラム吸着, カラム脱着の 繰り返し試験を行った6)。繰り返し過程に特ける リチウム吸着性および脱着性ならびに振とう試験 強度などの変化を調べた。粒状吸着剂の粒径は小 さくなるほど表面積が大きくなり, 吸着速度は向 上するが，摩耗性も大きくなると考えられる。そ こで比較的小さい粒径 $0.5 \sim 0.7 \mathrm{~mm}$ の粒状吸着 剤を用いた。

吸着一脱着の繰り返しを 10 回行った結果を Fig. 8 に示す。吸着剤 $1 \mathrm{~g}$ あたりのリチウム吸 着量 (左縦軸) は, 繰り返し回数とともに若干低 下したが，良好な吸着性能を保持している。リチ ウム吸着量の低下率は脱着処理に打ける吸着剂中 のマンガンの溶解損失率に対応している。さら に, マンガンあたりの吸着量（右緃軸）をみると 

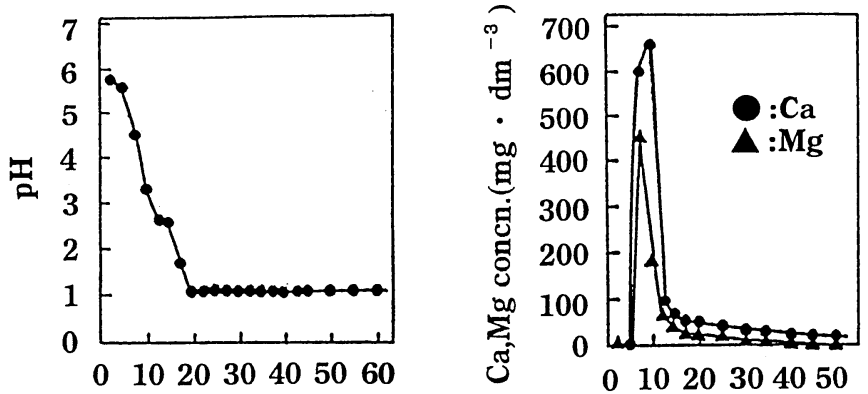

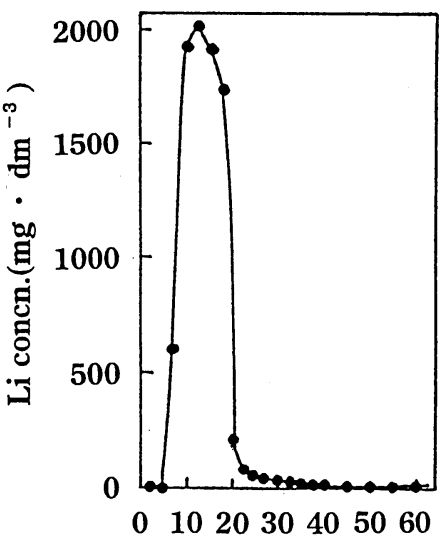

Volume of effluent $\left(\mathrm{cm}^{3}\right)$

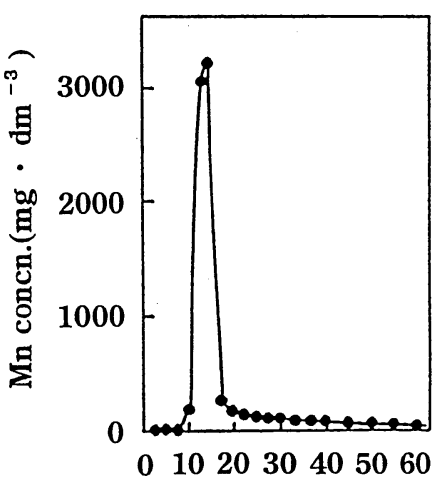

Volume of effluent $\left(\mathrm{cm}^{3}\right)$
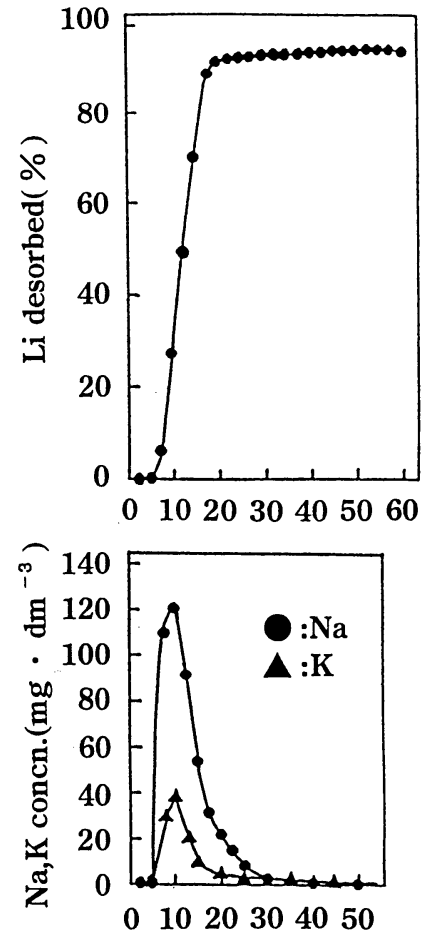

Volume of effluent $\left(\mathrm{cm}^{3}\right)$

Fig. 7 Column elution curves with granulated adsorbent.

Adsorbent: $10 \mathrm{~cm}^{3}$ (lithium uptake $16.5 \mathrm{mg} / \mathrm{g}$ ), column diameter: $0.8 \mathrm{~cm}$, eluent: $0.5 \mathrm{M} \mathrm{HCl}$, space velocity: $0.65 \mathrm{~h}^{-1}$.

ほとんど変化がみられない。従って，吸着剤の本 質的性能には変化がないものと考兄られ。ま た，脱着時のリチウム脱着率は $95 \%$ 程度で変化 がなく良好である。

リチウム吸着一脱着の繰り返し試験の際の他元 素の挙動を検討した。カルシウム，マグネシウ ム, カリウム, ナトリウムの吸着量は $3 \mathrm{mg} \cdot \mathrm{g}^{-1}$ 以下と少なかった。カルシウム拈よびカリウムは 酸処理で注ぼ定量的に脱着できた。しかし，マグ ネシウムとナトリウムの脱着率は低く（60～ 70\%）繰り返し吸着一脱着によって吸着剤内に蓄 積する傾向が認められた。

粒状吸着剤の物理的安定性は吸着性能とともに 重要である。そこで 10 回の吸着一脱着の繰り返 し過程での粒状吸着剤の振とう試験強度を調べ た。初期吸着剤と同じ強度 $(99.8 \%)$ を示し, 変

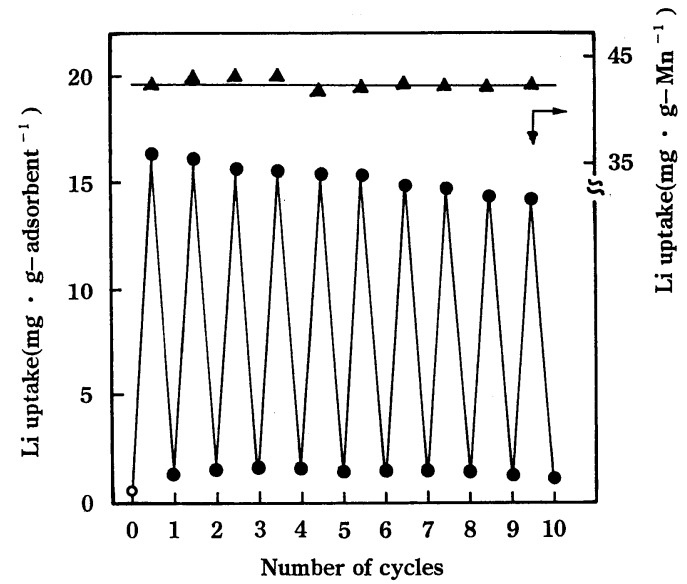

Fig. 8 Repetition of lithium adsorption-desorption cycle.

Adsorbent: $10 \mathrm{~cm}^{3}$, granule diameter: $0.5-$ $0.7 \mathrm{~mm}$.

Adsorption: 21 days at a space velocity of $450 \mathrm{~h}^{-1}$.

Desorption: $0.5 \mathrm{M} \mathrm{HCl}$ at a space velocity pf $0.65 \mathrm{~h}^{-1}, 10$ hours. 
化はみられなかった。また，長期の吸着一脱着の 繰り返し試験中に粒状吸着剤の破砕を伴う形状の 変化は観察されず安定であることがわかった。

\section{5. ベンチ試験}

\section{1 吸着実験}

海水からのリチウム採取システムの技術的な問 題点を把握するために, 粒状吸着剤を用いてカラ ム流動床方式によるベンチ吸着試験を行った ${ }^{11) 。 ~}$ まず, 海水からのリチウムを大量採取（炭酸リチ ウムとして $1 \mathrm{~kg}$ 程度）するためのベンチ吸着試 験装置を設計・試作した。ベンチ規模での吸着速 度および吸着一脱着の繰り返し試験, 脱着液から の炭酸リチウムの製造技術を検討し，リチウム採 取の収率を計算した。

装置の概略図をFig.9 亿示す。海水は貯水槽 から濾過器, ポンプ, 脱気槽を通って吸着槽の底 部から上向流にて流出させる。吸着槽は, 底部が 内径 $10 \mathrm{~cm}$, 高さ $100 \mathrm{~cm}$, 上部が内径 $60 \mathrm{~cm}$, 容量 $120 \mathrm{dm}^{3}$ の円錐台形である。この形状は底 部での海水の線速度を大きくし吸着剤の流動状態 をよくすること，ならびに，上部での線速度を小 さくして吸着剤の沈降を早め, 安定な流動床の形 成を意図している。材質は透明性ポリ塩化ビニル 製で内部の吸着剤の流動状態を観察することがで きる。粒状吸着剤の流出を防止するために, 吸着
槽の最上部に 16 メッシュのナイロン製網をとり つけている。海水の流量はポンプで制御し, 海水 温度は自動記録計にて計測する。

吸着槽に粒状吸着剂（粒径 0.25 2.8 mm） $2.5 \mathrm{~kg}$ (乾燥重量) を充填して, 海水を $15 \mathrm{dm}^{3}$ • $\min ^{-1}$ の流速（空間速度 $100 \mathrm{~h}^{-1}$ ）で通水して吸 着実験を行った。1 回の吸着処理時間は 28 日間 で, 実験期間中に吸着一脱着の繰り返しを 7 回行 った。海水温度は $15 \sim 25^{\circ} \mathrm{C}$ （実験期間 1993 年 1 月〜7月）であった。

本実験装置を用い海水流速と流動体積比との関 係を求めた。円筒型カラムを用いた場合に比べ高 流速領域で流動体積比が抑えられる傾向がみら れ, より安定な流動床が形成されることがわかっ た。今回の吸着条件では流動膨張比は 1.5 倍にな った。吸着剤の流動状態は良好で, ベンチ規模に よる影響はみられなかった。しかしながら, 吸着 剂の一部が海水表面に浮上した。浮上した吸着剤 を吸引・脱気すると再び沈降性を示すことから， 空気の付着によるものと考光られる。実用的に多 量の吸着剂を取扱う場合, 一つの問題点であると 考えられる。

吸着速度は実験室規模での吸着実験結果とよく 一致した。吸着時間 28 日間でのリチウム吸着量 は $12 \mathrm{mg} \cdot \mathrm{g}^{-1}$ であり, 平衡吸着量の $70 \%$ に達し た。

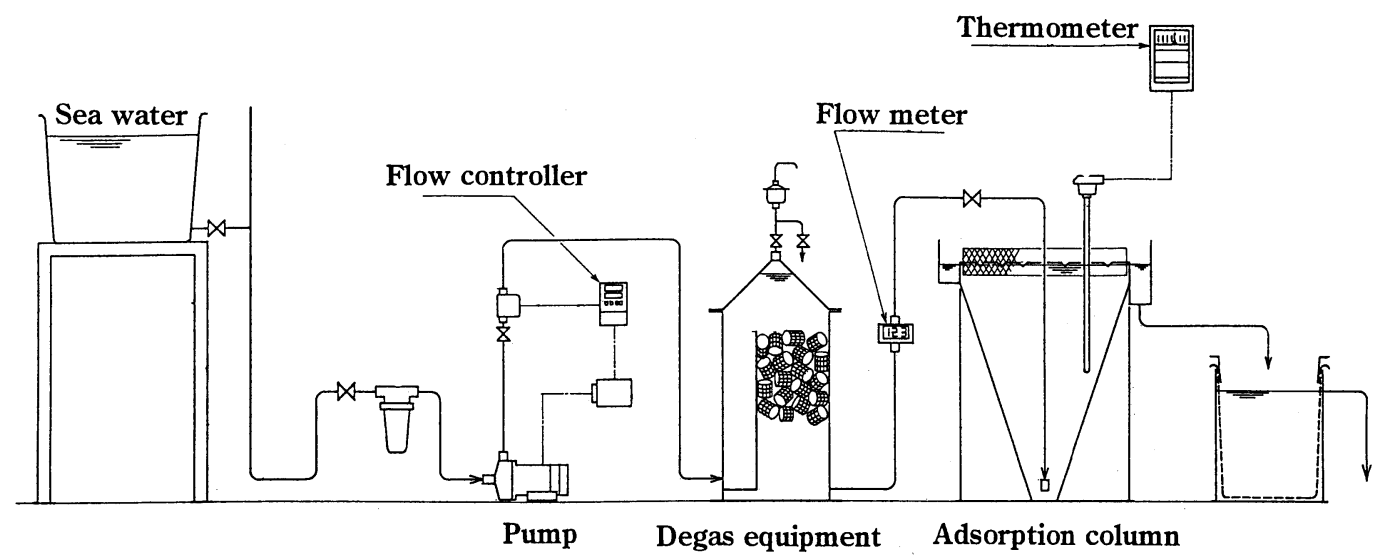

Fig. 9 Apparatus for bench-scale study on lithium recovery from seawater. 


\section{2 脱着と繰り返し試験}

リチウムの脱着は $0.5 \mathrm{M}$ 塩酸溶液を用いて回分 式 2 段脱着で行った。吸着槽の粒状吸着剂を 100 メッシュ・ナイロン製袋に移し入れ， $0.5 \mathrm{M}$ 塩酸溶液 $30 \mathrm{dm}^{3}$ 中に浸漬してときどき振とう し， 2 時間保持した。脱着液は酸を補充して 2 回 繰り返して使用した。

吸着一脱着の繰り返しを 7 回行った結果を Fig. 10 に示す。リチウム吸着量は繰り返し回数 とともに若干低下したが，良好な吸着性能を保っ ている。低下の度合は脱着の際の吸着剂の溶解損 失率に対応している5 ${ }^{5)}$ 。一方，脱着率は $85 \%$ 程 度で変化がみられなかった。な技，脱着操作の容 易な回分式を用いたため脱着率はやや低い值とな っている。

10 回の繰り返し試験においても粒状吸着剤の 形状の破砕を伴う変化はみられず安定であった。

\section{3 炭酸リチウムの製造}

脱着液からのリチウムの濃縮分離は予備実験結 果に基づき, アルカリ添加, 加熱濃縮, 晶析, 熱 水洗浄の工程で行った。その結果, 純度 $99.1 \%$ の炭酸リチウムを約 $750 \mathrm{~g}$ 製造することができ た。

製造炭酸リチウムの純度は $99 \%$ 以上で試薬品 位のものが得られた。不純物元素のらち, カリウ ム, マグネシウム, ストロンチウムなど海水から の混入と考兄られる元素の含量は $0.001 \%$ 以下で あり試薬特級品と同等であった。ナトリウム, カ ルシウム，鉄は若干高い值を示したが，吸着剤の 主成分であるマンガンは確認されなかった。

約 7 カ月間の吸着一脱着試験を行った結果を

Table 3 に示す。海水からのリチウム採取率は $27 \%$ であり, 最絡物の炭酸リチウムとしての収 率は $20 \%$ である。以上の結果から, 海水からの リチウム採取が技術的に可能であることを確認で きた。

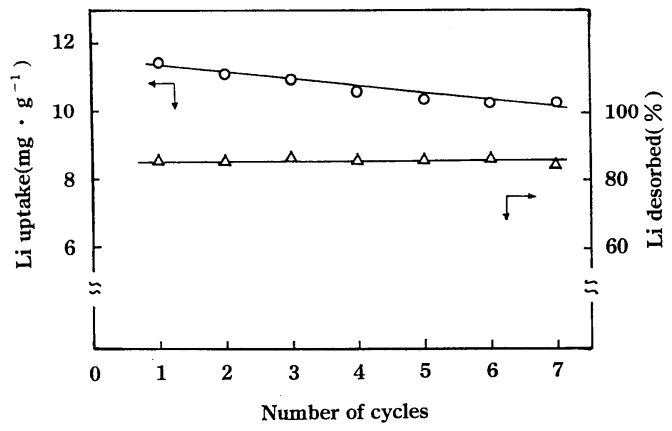

Fig. 10 Repetition of lithium adsorption-desorption cycle.

Adsorption: 28 days at a space velocity of $100 \mathrm{~h}^{-1}$, temp: $15-25^{\circ} \mathrm{C}$.

Desorption: $0.5 \mathrm{M} \mathrm{HCl}, 2$ hours.

Table 3 Results of bench-scale study on lithium recovery from sea water

\begin{tabular}{ll}
\hline \hline Adsorbent & $2.5 \mathrm{~kg}$ \\
Flow rate of sea water & $15 \mathrm{dm}^{3} \cdot \mathrm{min}^{-1}$ \\
Adsorption time & 28 days \\
Desorption time & $4 \mathrm{~h}$ \\
Adsorption-desorption repetition & 7 times \\
\hline Total volume of sea water & $4,233 \mathrm{~m}^{3}$ \\
Rate of lithium uptake & $27 \%$ \\
Amount of $\mathrm{Li}_{2} \mathrm{CO}_{3}$ produced & $750 \mathrm{~g}$ \\
${\text { Final yield as } \mathrm{Li}_{2} \mathrm{CO}_{3}}^{\text {Fin.1\%) }}$ & $20 \%$ \\
\hline
\end{tabular}

\section{6. リチウム採取システム}

海水のリチウム濃度が比較的高いために， ウラ ン採取の場合のように自然海流を利用する必要は ない。火力発電所およびその他の工業用の冷却用 海水などポンプ動力で利用されている海水を対象 としても充分な量のリチウムを回収できる。従っ て，リチウム採取システムは，自然エネルギーを 利用するものに比べ簡便となり装置コストも低く なると予想される。

発電所温排海水からのリチウム採取量の見積を Table 4 に示す。たとえば, 100 万 kw 級の発電 所の温排海水量は毎分 2,400 トンであり, リチウ ムに換算すると毎分 $400 \mathrm{~g}$ に相当する。海水量の 利用率を $80 \%$, リチウムの採取率を $25 \%$ と仮定 
すると年間に 42 トンのリチウムを生産できる。 我が国の火力発電所の最大出力の総和は約 8,800 万 $\mathrm{kw}$ であるから，全体としての採取量は 3,700 トン/年となる。リチウムの国内需要量は,リチ ウム換算で 1,300 トン/年であるので，採取量は 国内需要量の約 3 倍に相当する。温排海水から のリチウム採取は四囲を海洋と接する我が国にと って極めて有望なシステムである。

温排海水からの吸着装置としては, 流動床方式 で問題はないと考えている。また，脱着時に用い る酸としては発電所から排出される廃酸が使用で き, 炭酸リチウム晶析時に用いる炭酸根は火力発 電所から排出される炭酸ガスを用いることができ る。さらに, 火力発電所で余剩となった電力は, リチウム塩を金属リチウムに変換するために用い ることができる。温排海水を対象としたリチウム 採取システムの構築は, 将来的に極めて意義深い 研究であると考㝋ている。

発電所温排海水を用いるシステムの他にリチウ 厶採取船舶を用いる方法, 波力発電装置に付帯さ せる方法などが提案されて扣り, 今後の発展が期 待されている。

\section{7. 今後の課題}

スピネル型マンガン酸化物系吸着剤によるリチ ウム採取に関する研究結果をふまえ，著者らは Fig. 11 に示すリチウム採取行程を提案してい る。

実用化に向けて今後さらに解決すべき課題がい くつかあげられる。吸着剤に関しては，まず第一 に, 繰り返し吸脱着に十分耐えられるよらな化学 的に安定な吸着剤の開発を進める必要がある。ま た，吸着速度を上げるために高性能バインダーの 探索と多孔化技術の開発を更に進める必要があ る。また，吸着剤の值段を下げるためにマンガン 鉱石や中間製品からの吸着剤の大量合成法を確立 する必要がある。

採取システムに関しては, 現在のところいろい
Table 4 Calculation of lithium recovery using sea water passed through power plant

\begin{tabular}{c|c}
\hline \hline Flow rate of sea water & Lithium yield \\
\hline & $400 \mathrm{~g} \cdot \mathrm{min}^{-1}$ \\
& $576 \mathrm{~kg} \cdot$ day $^{-1}$ \\
$2.4 \times 10^{3} \mathrm{t} \cdot \mathrm{min}^{-1}$ & $210 \mathrm{t} \cdot$ year $^{-1}$ \\
& Possible yield \\
& $42 \mathrm{t} \cdot$ year $^{-1}$ \\
\hline $2.1 \times 10^{6} \mathrm{t} \cdot \min ^{-1}$ & Total possible yield $\left.^{\mathrm{a}}\right)$ \\
& $3,700 \mathrm{t} \cdot$ year $^{-1}$ \\
\hline
\end{tabular}

a) Running of plant: $80 \%$, total yield of $\mathrm{Li}: 25 \%$.

ろなアイデアを提案している段階である。まず, 吸着プロセスの一般的な定式化を行う必要があ る。これらの一般式を基に採取装置の概念設計， 詳細設計を行い，さらに経済評価を定量的に行ら 必要がある。実用化を視点においたシステム工学 的検討を通して, 海水からのリチウム採取が現実 化するものと期待している。

記号
A : 全粒子外部表面積 $=3 \mathrm{~W} / \mathrm{RNp}$
$\left(\mathrm{cm}^{2}\right)$
C ：液相のリチウム濃度
$\left(\mathrm{mg} \cdot \mathrm{cm}^{-3}\right)$
$\mathrm{C}_{0}$ : 液相のリチウム初濃度
$\left(\mathrm{mg} \cdot \mathrm{cm}^{-3}\right)$
$\mathrm{C}_{\infty}$ : 液相の平衡リチウム濃度
$\left(\mathrm{mg} \cdot \mathrm{cm}^{-3}\right)$
c ：固相中のリチウム濃度
$\left(\mathrm{mg} \cdot \mathrm{cm}^{-3}\right)$
$\mathrm{Dp}$ : 粒内拡散係数
$\left(\mathrm{cm}^{2} \cdot \mathrm{s}^{-1}\right)$

$\mathrm{k}^{2} \quad$ : 細孔の屈曲度

$\mathrm{n}$ ：フロインドリッヒ定数

$\mathrm{Q}_{0}$ : 濃度 $\mathrm{C}_{0}$ のときのリチウム吸着量

$\left(\mathrm{mg} \cdot \mathrm{g}^{-1}\right)$

$\mathrm{Q}$ ：濃度 $\mathrm{C}$ のときのリチウム吸着量

$\left(\mathrm{mg} \cdot \mathrm{g}^{-1}\right)$

$q$ ：粒子内のリチウム吸着量

$\left(\mathrm{mg} \cdot \mathrm{g}^{-1}\right)$

$\mathrm{R}$ : 粒子半径

(cm)

$r \quad:$ 粒子内の動径座標点

$\mathrm{t}$ : 吸着時間

(cm)

$\mathrm{V}$ : 液相容積

$\mathrm{W}$ : 吸着剤総重量

$\varepsilon_{\mathrm{A}}:$ 粒子の空隙度

$\rho_{\mathrm{A}}:$ 吸着剤の乾燥体積密度 $\quad\left(\mathrm{g} \cdot \mathrm{cm}^{-3}\right)$

$\rho:$ 吸着剂の真密度

$\left(\mathrm{g} \cdot \mathrm{cm}^{-3}\right)$

$\rho_{\mathrm{w}}:$ 吸着剂の湿潤体積密度

$\left(\mathrm{g} \cdot \mathrm{cm}^{-3}\right)$ 


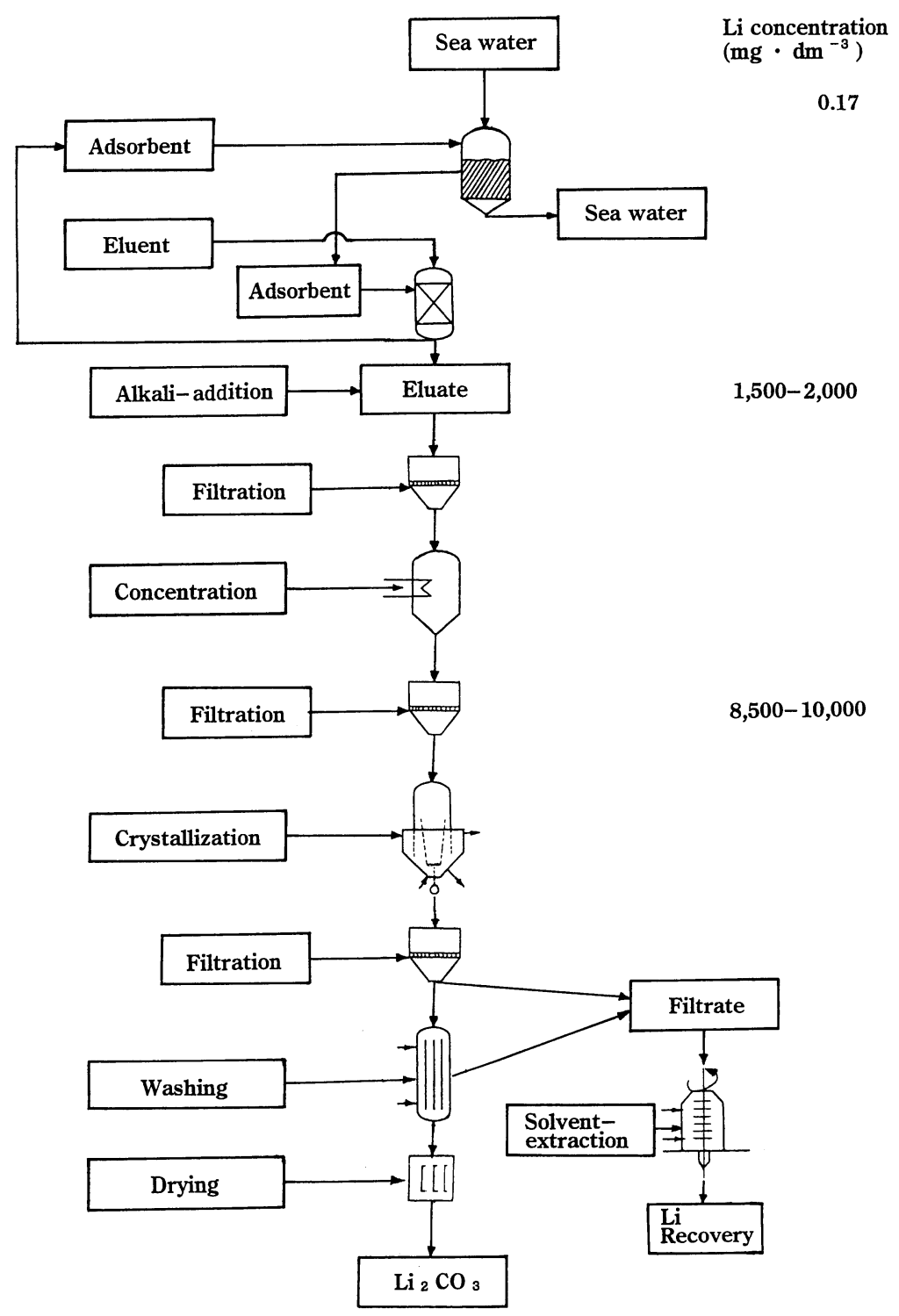

Fig. 11 Flowchart of lithium recovery from seawarter.

\section{文献}

1）大井健太, 宮井良孝, 加藤俊作, 阿部光雄, 海水 誌, 42, 219 (1989).

宮井良孝, 大井健太, 加納博文, 馮旗, 加藤俊 作, 四国工業技術研究報告, No 28, (1996).

2）隈本純二, “最新吸着技術”, (角田光雄監修), 総合技術センター，（1993）p. 579.

3) Y. Miyai, K. Ooi and S. Katoh, Sep. Sci. Technol., 23, 179 (1988).

4) Y. Miyai, K. Ooi and S. Katoh, J. Colloid Interface
Sci., 130, 535 (1989).

5）宮井良孝, 大井健太, 榊原実雄, 加藤俊作, 海水 誌, 45, 193 (1991).

6）宮井良孝, 大井健太, 西村友伸, 隈元純二, 海水 誌, 48, 411 (1994).

7）宮井良孝, 加納博文, 馮 旗, 大井健太, 海水 誌, 49, 347 (1995).

8) M. Suzuki, K. Kawazoe, Seisan Kenkyu, 26, 296 (1974).

K. Hashimoto, K. Miura, S. Nagata, J. Chem. 
Eng. Jpn., 8, 367 (1975).

K. Ooi, K. Ashida, S. Katoh, K. Sugasaka, J. Nucl.

Sci. Technol., 24, 315 (1987).

真田雄三，鈴木基之，藤本萓編，“活性炭 基礎

と応用”講談社サイエンティフィック $\mathrm{p} 86$, (1992).
9）河添邦太朗, 杉山衣世子, 福田義民, 化学工学, 30, 1007 (1966).

10）宮井良孝, 加納博文, 馮 旗, 大井健太, 海水 誌, 48, 416 (1994).

11）宮井良孝, 加納博文, 馮 旗, 大井健太, 海水 誌, 49, 226 (1995).

\title{
Manganese Oxide Ion-Sieves (3) Lithium Recovery from Seawater with Spinel-type Manganese Oxide
}

\author{
Kenta OOI ${ }^{1}$, Yoshitaka MIYAI ${ }^{1}$, Hirofumi $\mathrm{KANOH}^{1}$ and $\mathrm{Qi} \mathrm{FENG}^{2}$
}

1 Shikoku National Industrial Research Institute, 2217-14, Hayashi-cho, Takamatsu, 761-03 Japan

2 Faculty of Science, Kochi University 2-5-1, Akebono-cho, Kochi, 780 Japan

(Received Nov. 10, 1997)

\begin{abstract}
Summary
Spinel type manganese oxide shows a specific selectivity for lithium ions and is the most promising adsorbent for recovery of lithium from seawater. In order to develop a technology for lithium recovery from seawater, we carried out research works on development of spinel-type manganese-oxide adsorbent, granulation of powdered adsorbent, column adsorption and desortption, and bench-scale adsorption from seawater.

The powdered adsorbent obtained by the acid treatment of $(\mathrm{Li})\left[\mathrm{Li}_{0.33} \mathrm{Mn}_{1.67}\right] \mathrm{O}_{4}$ showed the largest lithium uptake (above $20 \mathrm{mg} / \mathrm{g}$ ) from seawater. The adsorbent was granulated with poly vinyl chloride as a binder. The granulated adsorbent maintained large adsorptive capacity for lithium and had a high lithium ion diffusivity. The lithium adsorption by fluidized bed column, the lithium desorption with an acid, and the repetition of adsorption desorption cycle were investigated. On the basis of these studies, a fluidized-bed type adsorption bench was designed and constructed using a cone-shaped column. $\mathrm{Li}_{2} \mathrm{CO}_{3}$ powder $(750 \mathrm{~g})$ with a purity of $99.1 \%$ could be recovered from seawarer by the 7 time repetitions of adsorption desorption cycle. Several R/D theme have been proposed for future practical utilization of the recovery system.
\end{abstract}

